\title{
RICE WITHOUT CHILLI: IDEAS OF SELF- SACRIFICE AND THE DESIRE FOR VIOLENCE IN BERSIH 4.0 AND 5.0
}

\author{
Vilashini Somiah \\ Department of Southeast Asian Studies \\ National University of Singapore \\ (v.somiah@u.nus.edu)
}

\begin{abstract}
To followers of contemporary Malaysian politics, the Bersih rallies have become synonymous with citizenry resistance and defiance. Organised by The Coalition for Clean and Fair Elections - an alliance of Malaysian nongovernmental organisations, Bersih (which carries the literal meaning of 'clean' in Bahasa Malaysia) sought to reform the present-day national electoral system and called for clean and fair elections. Bersih operates by occupying public spaces. The first of the rallies (2007), held in Kuala Lumpur, saw the participation of thousands. The state responded to the rally by setting up roadblocks throughout the city centre and was accused of police violence and unjust arrests. The same pattern occurred in Bersih 2.0 (2011) and 3.0 (2012) which saw a bigger turnout each time and was met by greater resistance by the state, where more arrests and violence were documented by the media. By contrast, state interference on the days of Bersih 4.0 (2015) and 5.0 (2016) was minimal. Despite the Malaysian government's usual warning of arrests and prosecution, police violence never happened at either rally, leaving participants and analysts questioning the motives of both the government and the protesters, leaving a sense of unfulfillment. Through ethnographic data and the use of news media, this paper will attempt to investigate and discuss how participants of the Bersih rallies have come to see themselves as selfsacrificing and how the presence and anticipation violence functions as an indicator of weak and corrupt governance. Applying Arendt's ideas of political violence (1970) as well as Girard (1977) and Fierke's (2013) notion of selfsacrifice of the political body further assists in deciphering how these rallies' peaceful endings may help reconceptualise how a desire for violence functions as an index of necessary change.
\end{abstract}

Keywords: Malaysia, Bersih rallies, rally goers, violence, self-sacrifice 


\section{Introduction}

As I stepped into the taxi the morning of 31 August of 2015, I found myself mesmerised by the streams of families and schoolchildren hurrying to get a seat at Merdeka Square. It was the annual Independence Day celebration, and the square was bustled with people ready to watch the national parade. Red, white, yellow, and blue balloons, (the colours of the Malaysian flag), were being given out to children free and food stalls selling local snacks and drinks added to the festivity. The atmosphere was light, and despite the lack of traffic control from authorities, vehicles and pedestrians took it upon themselves to be orderly and in line. The irony was not lost on me when less than 24 hours ago, the area around the Square was host to a much more serious affair; the Bersih 4.0 political rally, one I had specifically flown into Kuala Lumpur.

The journey to the airport takes approximately an hour from the city, and in wanting to stop myself from falling asleep, I began a conversation with my driver, Ah Khim, who had plenty to say about tax reforms, the annual haze and price hikes. As we approached the final tollbooth, Ah Khim brings up the Bersih 4.0 rally, which he claims to have always supported because he "doesn't like the government", but chose to sit it out that year to make some extra cash. He further justifies his absence at the rally by stating that Bersih 4.0 "wasn't worth attending" unlike previous rallies where "the police went crazy, beating, and arresting everyone." I ask how violence is ever good for anyone, and Ah Khim says that "before when they (police) attacked the rakyat (people), it meant they were wrong, and we were right. Now, when they do not attack us, it feels like the rakyat is wrong and cannot fight for our cause. Not having the police attack was like rice with no chilli... no 'kick' for the cause la." I pressed if he thought that all Bersih participants wanted this. He replies "of course not but they expect the police to be there. It's part of the fight for change."

Ah Khim's point felt strangely apt. I imagined that he represented a large majority of Malaysians who probably felt the same - that the Bersih 4.0 (and eventually Bersih 5.0) rally lacked the commonly expected forms of conflict, aggression and brutality which have transformed into an important component of the agency. The conversation with Ah Khim led me to believe that many who attended came with the hope that some form of contact with the state through the 2015 Bersih rally would result in the removal of current Prime Minister Najib from his alleged dictatorship and help cripple an already corrupted government. Of course, this contact never happened. Eventually, for both Bersih rallies, a peaceful gathering began and ended in both 2015 and 
2016 without any major violent interference. Reports on Bersih from both the organisers and the media were celebratory yet analytical over the peaceful proceedings.

\section{Framework \& Methodology}

This paper intends to make two claims. Firstly, a great deal of how participants prepared for the Bersih 4.0 and 5.0 rallies reflected on the previous three rallies held in 2007, 2011 and 2012 that was met with various forms of state-endorsed violence; unfettered use of water cannons and tear gas, arrests without trial and numerous accounts of police brutality. Although most of those arrested were eventually released without bail within hours, I argue that recent Bersih rally goers penetrated the city centre in the name of self-sacrifice, mentally and physically prepared to be confronted with violence, in great hopes of political change.

Secondly, I believe that the lack of violence during the two recent Bersih rallies has resulted in many participants feeling quizzically unfulfilled. Hannah Arendt's On Violence (1970), makes the case that violence exists in the face of dying power. In line with this, I posit that rally-goers sought to experience forms of violence to justify an illegitimate government despite the rallies zero tolerance on any forms of violence. The anticipation of violence has therefore transformed into a desire for violence that was not met because of violent free rallies. One possible view is that rally-goers were finally able to achieve some catharsis when a counter-rally to Bersih 4.0 and 5.0 occurred via the presence of United People's Rally, held in response to both Bersih 4.0 and 5.0 as a show of support for the Prime Minister and his administration.

Data for this paper is based on an ethnographic account of my experience at the Bersih 4.0 and 5.0 rallies that took place in August of 2015 and November of 2016 in Kuala Lumpur and will carefully attempt to deconstruct what it means to have a desire for violence and acts of selfsacrifice in Bersih 4.0 and 5.0 as a rite of passage. Together with the use of published news reports, it will also discuss how members of the United People's Rally are seen as agents of the state, whose sole function is to curb the Bersih movement but has inadvertently assisted with developing the ethos of self-sacrifice and providing closure to the desire for violence amongst many rally goers. 


\section{Bersih and Its' History of Violence}

Bersih means "clean" in Bahasa Malaysia. The event was organised by the Coalition for Clean and Fair Elections (BERSIH), a Malaysian NGO launched in 2006 that seeks to reform the current Malaysian electoral system in hopes of ensuring freer, cleaner, and fairer elections. Sparked by allegations of "corruption and discrepancies in the Malaysian election system that favoured the ruling Barisan Nasional (BN) coalition" (New Straits Times, 2015), the Bersih movement is believed to be "an extension of and tied in with the Reformasi movement which prospered after the imprisonment of the popular former Deputy Prime Minister Anwar Ibrahim in 1999" and was initially seen as elitists as well as a "political party-driven movement" by way of support by the middle classes of Malaysia, but eventually developed into "more of a grassroots movement" (Radue, 2012).

In 2010, the movement was re-named Bersih 2.0 declaring its position as a "fully non-partisan movement free from (any) political influences" (The Straits Times, 2015). At the core of the Bersih movement is its' eight demands, amongst them: updating of the electoral roll to remove "phantom voters" specifically deceased persons, multiple persons registered under a single address or non-existent addresses, reform of postal ballot to allow voting not only for Malaysian citizens living abroad, but also those within the country who cannot vote in their constituency on polling day, the use of indelible ink to prevent voter fraud and a minimum 21 days for campaigning to allow voters more time to gather information and deliberate on their choices (The Straits Times, 2015). Bersih rally supporters and organisers stand firm that these demands have yet to be met.

Bersih rallies operate by occupying public spaces in which participants are encouraged to wear yellow (colour of the Malaysian royalty and a symbol of strength and unity) and participate in walking towards and the occupation of public areas around the country such as Merdeka Square in Kuala Lumpur. The debate around the demographics of rally goers has suggested that those who participate are of the "entrepreneurial middle classes" who were not dependent on the government the way "salaried middle-class Bumiputeras" were (Abdul Rahman, 1999, p. 108). Scholars have been very critical of the support by the Malaysian middle classes as they have been perceived as a class that "suffer from a lack of identity coherence, boundedness, and selfconsciousness" as a result of "heterogeneity" (p.116). However, Bersih 2.0 and 3.0 rallies indicated a major turnout of middle-class Malay ethnic groups citing 
an attraction for the movement's core values, proving that Bersih was able to break racial barriers and was indeed a movement on a national level.

To date, the Malaysian government has only addressed, albeit lackadaisically, the national voting registry, political campaign periods and the use of indelible ink but have not responded to the remainder of Bersih's demands. Organisers and participants of the rally have been continuously vocal in addressing their concerns about their unmet demands through chants, songs, posters, placards, and banners leading to intense interruptions by the state in the form of police brutality for the first three rallies. The first Bersih and Bersih 2.0 saw over a thousand rally goers arrested and punished without trial. With a turnout of anywhere between 30 to 90 thousand people per rally, the police resulted in the use of "tear gas and chemical-laced water cannons to stop demonstrators from their march" (The Straits Times, 2015). Police abuse and brutality were also sighted, with images of bleeding and bruised rally goers roughened by groups of plain clothed police officers made their rounds in social media. As explained by Thiruchelvam (2011), with "international media, such as CNN, BBC and Al-Jazeera (reporting) on the magnitude and details of the rally... the local police (were) criticized to have acted harshly (firing water cannons and tear gas) at the peaceful protesters who were marching to the Istana Negara (The National Palace) to hand in their memorandum to the King" (p. 86). Despite this, only one death has been reported throughout the entire Bersih movement due to a heart attack and not due to violence.

By Bersih 3.0, the movement sought the participation from Malaysians outside of the capital and gatherings were held simultaneously throughout the country. Despite an attempt at the peaceful congregation, most rally sites reported a descend into chaos as "scuffles broke out" (The Straits Times, 2015) among participants and police officers were forced to intervene violently. Bersih 3.0 also saw opposition leader Anwar Ibrahim "charged with participating in a street protest, but a Sessions Court later ordered a discharge not amounting to an acquittal" (The Straits Times, 2015). As such, violence towards a majority middle-class rally resulted in making the state and its agents a common enemy hence unifying these multi-ethnic experiences and successfully raising public attention around the aggressive misconduct of the police during the rally itself provoked further participation in Bersih (Radue, 2012).

The need for Bersih 4.0 thus arose when the country's leadership became embroiled in corruption and graft scandal that was perceived to be negatively impacting the country's economy. Although Bersih 4.0, like that of 
the previous rally, was held simultaneously in the states of Sabah and Sarawak as well, a greater attendance was met at Kuala Lumpur, as the urgency to gather was stronger felt in the capital than anywhere else. 1Malaysia Development Berhad (1MDB), a government endorsed development company came under fire when several foreign and local investigative blogs and news portals showed evidence that the Prime Minister, Najib Razak and his circles, pocketed an alleged sum of money.

In a move to consolidate his position, he sacked Attorney General Gani Patail and Deputy Prime Minister Muhyiddin Yassin through a sudden cabinet reshuffle much to the dismay of the rakyat. Hannah Arendt explains that

"Terror, tyranny, and dictatorship turn not only against its enemies but its friends and supporters as well. The climax of terror is reached when the police state begins to devour its children and when yesterday's executioner becomes today's victim. It is at this moment that power disappears entirely." (Arendt, 1970, p. 55)

The belief that these crimes were impacting Malaysia's socio-economic conditions became an apparent motivation for most rally goers. Bersih 4.0 was eventually declared illegal by the Malaysian Home Ministry and cited "failure to furnish permissions from premises owners to use their locations as rallying points" as a reason for the ban. Police also warned rally goers that they could "face legal action under the Peaceful Assembly Act" if arrested on that day (The Straits Times, 2015). However, as we have come to know, this never happened.

The movement made a comeback in the following year in 2016, when the Bersih committee called for "the fifth edition of the electoral watchdog's street rally" to be held on November 19, 2016. Similar in gist to the previous rallies, Bersih 5.0 demanded "reforms to become a national agenda, the parliamentary democracy system to be strengthened, and for the prime minister (Najib) to step down." (Malay Mail Online, 2016). In preparation for Bersih 5.0, the committee had also announced a nationwide roadshow several months before the main event to help build momentum and support for the rally. Bersih 5.0 together with members of the United People (red shirts) was also declared illegal, this time by the Inspector General of Police. Many Bersih supporters questioned the government's ability to act impartially during the rally despite issuing a warning to both camps.

By the Bersih 5.0 rally, a total of " 15 activists and members of the political opposition have since been arrested" including Bersih chairperson 
Maria Chin Abdullah "who was taken in under the Security Offences (Special Measures) Act or SOSMA - a new security law meant for terrorists (which) enables officials to arrest and detain people without a warrant and bail" (CNBC, 2016). On the eve of the rally, the Malaysian police also took to raiding the Bersih headquarters in the city of Petaling Jaya and confiscated items such as laptops, mobile phones, and various documents.

\section{Negotiations of Self- Sacrifice}

I was invited for dinner at a pub not too far away from the square the night before Bersih 4.0. Arriving 15 minutes later than everyone else, the pub was abuzzed with excited chatter and filled with a great many of the patrons wearing yellow. I made a beeline to my friends who were already enjoying a drink each and were already in the thick of discussion whilst waiting for my arrival. "It's going to be crazy tomorrow, but regardless of what happens, it'll be worth it. May our beloved country prosper and recover!" said one friend, followed by another friend- "Yes, anything can happen tomorrow, but we must be prepared for anything. Let's hope this will be the one to bring those bastards at the top down!" It was at this point that we shared with each other Facebook messages citing cheap and effective ways of surviving tear gas and phone numbers of lawyers on standby in the event of an arrest. Nearby tables also shared similar discussions but despite the unsettling idea of a swollen face and police handcuffs, spirits were high, and I, like many at the pub that night, bought into an altruistic ethos in the face of a political movement.

Have Bersih rally goers always expected to be confronted by state violence, embodying the ideals of self-sacrifice to abnegate political power and how is this different from it being a rite of passage through the simple the act of participation? To understand self-sacrifice, I turn to Rene Girard and his use of sacrifice in Violence and the Sacred (1972). Using contemporary fictional texts and mythology, Girard's classic pays attention to the cultural order of societies that are violent due to an inevitable sense of rivalry and competition. The desire to obtain what everyone else wants to lead to conflict in what Girard calls "mimetic desires". These desires need to be combated and tamed through the sacrificing of a "scapegoat", a member of the community that is also removed in a way that makes them disposable. Girard makes the claim that violence and sacrifice go hand in hand to reach its ultimate goal of peace and in line with my argument, that "many of our problems are the direct result of the concentration of wealth, power [and] exploitation" (1972). 
Yet, the concept of sacrifice differs from self-sacrifice, notably through the word "victim" and the idea of agency. Where Girard points out that sacrificial rituals are done to appease and marshal states of conflict, what differs here is the will of the sacrificed. Karin Fierke, in her book Political SelfSacrifice: Agency, Body and Emotion in International Relations (2013) explains that "Sacrifice and self-sacrifice are not the same but share a 'family resemblance' "(p. 33). She explains here:

"In respect to political sacrifice, the sacrificed was more an agent than a marginalised scapegoat. Members of subordinated and marginalised communities sacrificed themselves on behalf of justice for an entire community. This form of self-sacrifice is based on an institutionalised policy of recruitment, the recruit is by no means a scapegoat but is viewed as a heroic member of the community." (Fierke, 2013, p. 36)

Fierke stresses the importance of "suffering" to raise awareness of a community's political stance. She explains that there exist three main ideas around the idea of self-sacrifice - first that the community to benefit from the act of the actor, secondly, that the act of self-sacrifice has an objective which is "the restoration of the beneficiary's right to be independent" (p.5) and third, that "the self is sacrificed for a well-defined, demarcated social community" (p.6). As such, Fierke argues that the act of self-sacrificing weighs heavily on the use of the "actor's body", which is "arguably...a weapon of political battle, if not technically war" (p. 238). Hence, Fierke identifies self-sacrifice as an "act of speech" in which the "suffering body communicates the injustice experienced by a community to a larger audience... the sacrifice of the material body" (p. 37). Ultimately, the main point is that acts of "self-sacrifice communicates to an audience and produces consequential effects. The act is perlocutionary, in that it will often produce effects in the feelings, thoughts, or actions of the audience" (p. 37).

It is easy to see how Bersih rally goers can embody ideas of selfsacrifice. The participants attend in an attempt to right a national wrong, which will eventually be beneficial for the greater good of Malaysia. The act of suffering here is understood as these imagined and previously witnessed confrontations with the state in its' various forms. As threats of arrest and confrontation have been widely circulated in both mainstream and alternative media and further perpetuated by social media, it is difficult to assume that 
rally goers attend these rallies without prior knowledge of these points of conflict. By physically attending Bersih rallies, rally goers have prepared themselves to use their bodies as "weapons" through the act of resisting arrests, tear gas and water cannon attacks whilst articulating their unhappiness towards the state. A willingness in accepting state endorsed attacks on themselves proves that by and large Bersih goers see themselves as sharing the same language, feelings and thoughts of dissatisfaction and discontent towards the government.

But just as important a question is to see if participation in Bersih may also be considered a rite of passage for many Malaysians. Fierke makes specific mention of forms of self-sacrifice in the form of suicide bombing, hunger strikes and self-immolation; acts that can lead to possible death. An example of such show of self- sacrifice would be the Arab Spring was a series of Middle Eastern revolutionary waves that began in 2010 in hopes of bringing change to their respective political landscapes. Although the movement saw protesters gather in non-violence throughout city centres, it resulted in the death of hundreds of thousands and the displacement of millions.

But this differs in acts of self-sacrifice in relation to Bersih as it does not in any way imply possible death. Rumours and advice shared amongst supporters' stress policing that can be aggressive and practices punitive forms of punishment, however, rally goers attend Bersih believing there is no possibility of death. Self-sacrifice as a Bersih rally-goer is thus open to a few possibilities of violence but not death. Attending a Bersih rally has since become a rite of passage for many Malaysians who support the movement while providing them with some bragging rights to validate having suffered for a national cause in the fight for a just political system. It is this lack of deadly violence, as I perceive that makes the desire for violence is so much more appealing.

\section{The Desire for Violence}

Before I proceed further, it must be stressed that the Bersih movement has always maintained, to the media, critics, and participants, that it holds a zero tolerance on any form of violence. Throughout the years and in all five of its rallies, Bersih organisers have engaged with rally goers the importance of keeping calm and civil with the authorities and instigators as well as to avoid aggression at all costs. As an organisation, they have openly condemned threats and abuses directed at and performed by Bersih supporters alike. Therefore, my theory on desiring violence in the provocation of it (although 
this should not be ruled out entirely and be open to future discussion), but in the anticipation and expectation of acts of violence to occur.

Hannah Arendt's theory of power and violence through her acclaimed book On Violence criticises greatly the advocacy of violence by the Left wing in the 1960s and 1970s and makes a cautious reproval of the dangers of violence. She explains here that "All political institutions are manifestations and materialisations of power" yet these powers "petrify and decay as soon as the living power of the people ceases to uphold them" (Arendt, 1970, p. 41). Working around the key point she makes that violence "can always destroy power" and "what can never grow out of violence is power", (p. 53), it is possible to understand that such a desire for violence would help Bersih organisers and their participants prove that the Najib administration is a powerless, incompetent government.

Looking back at my conversation with Ah Khim, I must admit to being initially shocked by the suggestion that violence was appealing to him or any Bersih participant. It seemed unfathomable that anyone who attended the rally was eager to be dealt the same brutality from rallies of the yesteryears. As a past participant myself, the memory of being tear gassed was enough to make my heart stop as I vividly recalled the taste of aerosol in my mouth while my eyes struggled to grant me vision through the sting. An hour after the ordeal, my mouth and nose continued the overproduction of mucus and snot, forming a trail of crusty dried liquid down my shirt. Surely no rally goer wanted to experience that, and yet, the deeper implications of Ah Khim's words were, perhaps they did in the name of self-sacrifice.

The morning of both Bersih 4.0 and 5.0 rallies saw the similar routines, thousands of people making a beeline for Dataran square with their vuvuzela's and other noise makers. The aim was to always make as much of a presence as possible, a sign of defiance and pride. Many groups bore creative placards with jokes and digs at politicians from the ruling coalition, while a majority chanted "Bersih!" "Bersih!" in unison. My experience at both Bersih 4.00 and 5.0 was initially filled with a prepared people, daring anyone to stop them. Many rally-goers like myself brought with them gas masks and all sorts of protective gear in the event of a tear gas attack. One participant, I met at Bersih 4.0 had on winter gloves, and a body pad in case canisters was shot in his direction. While walking, he confessed that he would rather be sweaty that bruised.

As it has been since the very first rally, Merdeka Square was blocked from all entrances. The Malaysian government has made every attempt to ensure and inform that the one space rally goers were forbidden from entering 
would be Merdeka Square. At Bersih 4.0, rally goers were made to travel between five meeting points scattered around the periphery of the square. A designated speaker hosted every meeting point to rally the crowd, urging them to be brave and strong and fight against a cruel regime that wanted to cripple them with fear, inequality, and poverty. But these words seem to have lost a little bit of its meaning by the end of the day, when no Federal Reserve Unit (FRU) trucks, police cars or army tanks were seen. As the day gave way to night, many rally-goers would still gravitate towards the barricaded entrances of Merdeka Square, only to be told by Bersih organisers to back away. A young man next to me said the rakyat had the right to the square and everyone should fight to enter the space. This got several other rally goers excited, but this ended as quickly as it began with some in the crowd calling out "Sabar!" (be calm) and "Jangan!" (don't). Without a doubt, the tense and electrifying atmosphere felt by Bersih 4.0 rally goers in the morning seemed to have vanished by the late evening.

On the morning of the second day of the rally, a news article by the Malay Mail online read "No violent crackdown as government perceives Bersih 4.0 harmless, analysts say" (Ar, 2015), explaining that the Malaysian government, through its "mature response" understood the "public's needs" and the "meaning of democracy" hence seeing no danger in the Bersih 4.0 rally. Shamsul Adabi, the quoted analyst, suggested that Bersih 4.0's "lack of aggression" this time around might have given it a "perception of little impact" among the ruling coalition. "If there is no violent gathering, it will not affect a toppling of the country's leadership," (2015) explained Shamsul further. Liza, a friend from dinner at the pub, tells me she felt somewhat underwhelmed by the article. "I'm thrilled by this, I mean, it only took a little over 50 years (laughs). But it's still a little strange knowing we won't be stopped or arrested or attacked. I suppose I've been expecting them."

Fifteen months later, the atmosphere on November the 19th, 2016 resembled that of the previous one. As early as 10 a.m., Bersih 5.0 rally goers gathered at two separate locations (the National Mosque and Bangsar Road) all with the common goal of eventually converging at Merdeka Square. Clearly, the rally still boasted the same aura of the revolution that spiced the previous one despite appearing to be significantly smaller in size. This would be one of the main criticisms made on the rally for being held too soon after Bersih 4.0 and saw an attendance of only approximately "15,500... (compared to) the tens of thousands of protesters marched into the capital during Bersih 4.0" (Malay Mail Online, 2016). At Jalan Tun Perak, the main road leading to Merdeka Square, I was immediately greeted by a plethora of independent 
street vendors selling Bersih merchandises, many of whom conducted business amongst chanting rally goers. This, of course, was made donning yellow easier for many who came without.

Pushing my way further through the crowd, mobility felt laboured and occasionally at a standstill. In seeking out a foreign journalist friend covering the event, I was told to meet him in front of the FRU barricades set up to cut off access to Merdeka Square. The GPS I brought indicated a threeminute walk to the barricades but with the crowd, now seemingly agitated from the heat and lack of direction, my crawl took a little under twenty minutes. A glimpse at smaller lanes in perpendicular to Jalan Tun Perak showed many rally goers leaving the event, perhaps in response to not being able to proceed to Merdeka Square. Upon finally meeting my friend, I was able to note about eight to twelve FRU trucks and several other police vans all parked next to rows of water filled plastic barricades and barbed wires. The officers present were on guard but not engaging with civilians. "Nothing is happening, and people are getting a bit bored," said Michael, the journalist, who has covered four out of the five rallies. When I pressed what "nothing" meant, Michael tells me "the lack of any confrontation". As we spoke, two police vans wailed their sirens, a signal for rally goers to give way. As they inched through the crowd, rally goers began to both boo and cheer, many waving their placards, flags and yellow coloured objects at the unresponsive officers in the vehicles.

Word soon began to spread that because of the barricades set up, the rally was now moving to the entrance of Suria KLCC shopping centre, which hosted the famous Petronas twin towers. What was left of the crowd at this point decided to make it by foot or underground rail? In a conversation with Roga on the rail, a gentleman of 65 , he tells me that the switch to KLCC is a brilliant idea. "They (authorities) have been expecting us at Merdeka Square every year. 34-hour Give them something to sweat about." I ask if he might be worried about stronger police presence by occupying KLCC, he said no and added that even if the police became violent, not only would foreign media be watching but this time, tourists. "All those tourists at KLCC will see for themselves how the government regulates us with water cannons and tear gases. It's effective if they saw it live," stresses Roga.

Arendt explains that "Rule by sheer violence comes into play where power is being lost" (p. 53) and that "the extreme form of violence is One against All" (p. 42), and if Bersih 4.0 and 5.0 needed to deliver this message of a lost government, "sheer violence" was a necessary component. The level of influence the Bersih movement can possess is directly influenced by the 
amount of violence that arises from it. Bersih intends to prove as best possible that "the loss of power becomes a temptation to substitute violence for power (as) violence itself is a result in impotence" (p. 54). But this was not achieved during both the Bersih 4.0 and 5.0 rallies. Despite some state presence at Merdeka Square, a 34-hour sit in 2015 and a change of venue at 2016, rally goers were not met with the usual forms of brutality and violence from the yesteryears.

\section{Welcoming Ferocity?}

Despite not being met by state violence at both Bersih 4.0 and 5.0, I argue that some catharsis was achieved through the presence of United People's Rally also known colloquially as the Red Shirts. In both 2015 and 2016, a series of videos were released showing a large group of men which "consisted of a coalition of Malay non-governmental organisations" (Rakyat Post, 2015) making a show of violence by "smashing wood and roof tiles on their backs and heads" as part of their "self-defence preparations should trouble ensue between the "red" and the "yellow"" (Rakyat Post, 2015). Dressed in red (the colour of ruling political party UMNO), these members of the United People's Rally claimed to have a following of 30,000 and were ready for "a fight" in order to "show support for the government that was elected by the majority of Malaysians and to ensure Malaysia remains a peaceful and harmonious country" (Rakyat Post, 2015).

On the 16th of September 2015 (Malaysia Day), the United People's Rally (also known as the red shirts) took to the streets of Kuala Lumpur, in the same manner, Bersih 4.0 supporters did - boldly and loud. The organisers articulated the importance of the counter rally to show solidarity to Prime Minister Najib and his office, defend the special rights of the Malay community, take action against traitors of the state, and to safeguard the status of Islam in the Federal Constitution. As several online media provided live coverage of the ongoings, many who watched were appalled that this rally was allowed to do what Bersih wasn't; enter Merdeka Square, understood to be a legitimising strategy by the government. Live news reports showed a crowd ready for violence, through its use of racial slurs and profanity targeted at the non-Malay and non-Muslim community, whom red shirt supporters pegged and identified as being anti-government and non-nationalistic.

This was not an isolated case nor was the last time members of the red shirts called out for their attack on the Bersih movement. In 2016, the red shirts returned, this time under the leadership of Jamal Yunus who called for a 
counter rally to Bersih 5.0 which he claims to be "a threat to (his) religion and democracy" (The Star, 2016). Bersih organisers and volunteers have since reported a series of violent attacks throughout the campaign, in which one case saw several members of the Red Shirts physically assaulting a Bersih supporter in the town of Sabak Bernam. Adding to that, current Bersih chairperson, Maria Chin and-and several exco members have also received death threats by anonymous sources while the Malaysian government has threatened to blacklist government-linked businesses funding Bersih 5.0. Nevertheless, these publicised attacks did very little to kill the momentum of the preparation and resulted in an increase of support from religious leaders such as Catholic Bishop Bernard Paul along with politicians and political activists putting out a stronger call for greater support. It is necessary to point out that this fifth instalment of Bersih has also been met with mixed emotions and debates on the relevance of another rally, but if anything, these discussions have only increased general discourse on Bersih.

Red Shirt participants on the morning of the Bersih 5.0 rally in November 2016 also suffered a significant dip in numbers, with only 4,000 members gathering on another side of the city. Starting near the Sogo shopping complex, the Red Shirt group attempted to converge with the main Bersih group but were thwarted by police blockades throughout the city (Malaysiakini, 2016). Cut-off, the group dispersed quickly and never encountered the main Bersih group. Despite that, their presence was largely non-violent, but they were still a disruptive presence (The Malay Mail Online, 2016). Leading up to the Bersih 5.0 rally, the Red Shirts were involved in various violent outbursts involving Bersih participants, which led to them being labelled a violent group (The Star, 2016).

The argument on whether or not violence experienced through the United People's various responses was too far detached to make any impact, in my opinion, is irrelevant. What I believe was important for anyone affiliated to Bersih is that violence was needed to prove the illegitimate and felonious nature of the Malaysian government. This was possible through the red shirt rally of 2015 and 2016 and Bersih 5.0 Roadshow attacks (2016) that very obviously opposed the very nature of the Bersih movement. Their function as agents with affiliation to the state made it possible for Bersih supporters to view these encounters as state-endorsed violence.

Members of the red shirt rally were, therefore, seen as agents affiliated with the state. J. Schwarzmantel explains that "a centralised state gave rise to a source of power through these state agents which could be deployed against its citizens" and as such, these agents are entrusted with "sole legitimate use of 
violence" (Schwarzmantel, 2011, p. 63). I argue that as agents of the state, red shirt rally goers "resort to violence, to defend the existing structures of power" (p. 33) and themselves "perpetrate acts of violence against ... opposing forms of order" (p. 37) as instructed by the state. However, the method of control by such an arbitrary power is seen in the attacks later made on to members of the red shirt rally who tried to force their way into Chinatown in 2015 and the Bersih 5.0 rally in 2016. Police personnel took to arresting and regulating red shirt members and in 2015 began launching water cannon attacks to break the rally up after rally goers began throwing rocks and sharp objects at shop windows and the police. Both red shirt counter rallies ended prematurely without affecting much of the Bersih movement in general.

\section{Conclusion}

The Bersih organisation has long proclaimed to use peaceful, non-violent, and law-abiding assemblies to spread their message and agenda. However, up until Bersih 4.0 and 5.0, that goal was never achieved as the state has always confronted rallies with aggressive police intervention followed by criminal proceedings over those caught. Thus, these actions by the state have become an accepted premature but guaranteed end for all Bersih rallies which has led to what I discussed above as making it a rite of passage or self-sacrificial act for rally-goers. As such, there was also the possibility that if the police did not engage in violence at first, then some more assertive rally-goers would make that push instead. However, I believe that the Bersih organisers were aware of this and had always taken the necessary efforts to curtail it.

Even though the police disallowed the rally to congregate at Dataran Merdeka, they have allowed the organisers to assemble right at the edge of it. With Bersih 4.0, organisers took this opportunity to set up a makeshift stage there for speeches and performances, and this became the main gathering point for the entire rally. The Police allowed the rally to gather this close to the square as long as they did not breach the barriers. Utilising the bleachers meant for the Independence Day parade as a wall, the organisers set up a perimeter behind the stage with dozens of security personnel to ensure that no rally-goers would be able to get into Dataran Merdeka and cause the police to get involved. One could insist that this was the result of the Bersih 4.0's ability to react to an emergent situation given the circumstances, but I argue that they were well-prepared for the possibility of self-sacrificial rally-goers, hanging large printed banners that bore the message "Terima kasih kerana tidak memasuki 
Dataran Merdeka" ("Thank you for not entering Merdeka Square"). The Bersih 4.0 committee were fully aware.

It a sudden twist the following year, the Bersih 5.0 organisers decided to make a last-minute change of venue to Suria KLCC Shopping Mall and held the remainder of the rally from 3 p.m. till 6 p.m. completely uninterrupted. The open space of the main road and decorated walkways of the shopping centre made it easier for rally goers to spread out and make their presence felt in a now renowned commercial area of Kuala Lumpur. Some rally-goers vocalised this change as having to be prepared again for any possible confrontation, as an act of self-sacrifice but although closely monitored, authorities had again allowed Bersih 5.0 to carry on with their plans. By 6 p.m. the arrival of a thunderstorm and the lure of a warm shopping mall ended Bersih 5.0 that once again for the second year in a row, could attract a sufficient number of rally goers and distanced supporters from around the world, but could not do enough to shake the grounds of corruptors they sought to remove.

As such, Bersih 4.0 and 5.0 stand as a litmus test to determine if political causes can rise above the need for debasing violence to provide justification and satisfaction for supporters who attend. Both rallies could achieve their goal to fully stage a non-violent street protest on both occasions, but in a sense, many of the rally-goers did not achieve the catharsis from previous rallies. Bersih rallies have always been a space to vent what Arendt calls "rage". She explains that "only where there is a reason to suspect that conditions could be changed and are not, does rage arise (and) only when our sense of justice is offended do we react in rage " (Arendt, 1970, p 63).

The acts of self-sacrifice, rites of passage and ultimately a show of violence from the state to show that they were afraid of losing power were all absent in August 2015 and November 2016. While some satisfaction came in the form of the United People's Rally (the red shirts), the result of this peaceful outcome has changed the dynamics of Bersih rallies in general as the element of violence, or the lack thereof, is an indicator of the success or failure of Bersih in making their demands.

Members of the Red Shirts have become the new proxy for the government in providing the element of violence towards Bersih. While they can be considered surrogates of the government, and thus offer some form of satisfaction when they resort to violence, it is still an indirect justification and one the government is probably fully aware of. In a sense, Bersih supporters rely on this lesser form of catharsis to sustain their devotion to the cause but with this in mind, can the Malaysian left ever find a way to achieve political change without violence of any sort? Perhaps Bersih 6.0 may tell. 


\section{References}

Ar, Z. (2015, August 30). No violent crackdown as government perceives Bersih 4 harmless, analysts say. The Malay Mail Online. Retrieved from http://www.themalaymailonline.com/malaysia/article/no-violentcrackdown-as-government-perceives-bersih-4-harmless-analysts-say Arendt, H. (1970). On violence. London: Lane.

Chandran, N. (2016, November 20). Bersih 5 protest: a Fresh clampdown on Malaysian activists won't work, say critics. CNBC. Retrieved from http://www.cnbc.com/2016/11/20/bersih-5-protest-fresh-clampdownon-malaysian-activists-wont-work-say-critics.html

Embong, A. R. (1999). Malaysian middle-class studies: A critical review. In J. K. Sundaram (Ed.), Rethinking Malaysia (Vol. 1, pp. 107-125). Kuala Lumpur: Malaysian Social Science Association.

Fierke, K. M. (2013). Political self-sacrifice: Agency, body and emotion in international relations. Cambridge; New York; Cambridge University Press.

Firdaws, N. (2015, August 25). Anti-Bersih protesters 'beat' each other up with sticks and roof tiles (video). The Rakyat Post. Retrieved fromhttp://www.therakyatpost.com/news/2015/08/25/anti-bersihprotesters-beat-each-other-up-with-sticks-and-roof-tiles-video/

Girard, R. (1977). Violence and the sacred. Baltimore: Johns Hopkins University Press.

Kamal, S. M. (2016, November 20). Three things we learned from: Bersih 5. The Malay Mail Online. Retrieved from http://www.themalaymailonline.com/malaysia/article/three-things-welearned-from-bersih-5

Kumar, K. (2016, October 1). Punches fly as yellow, red-shirts clash in Perak (VIDEO). The Malay Mail Online. Retrieved from http://www.themalaymailonline.com/malaysia/article/punches-fly-asyellow-red-shirts-clash-in-perak-video

Kumar, K. (2016, September 14). Bersih 5 on November 19. Malay Mail Online. Retrieved from http://www.themalaymailonline.com/malaysia/article/bersih-5-onnovember-19

Kumar, M. (2016, November 12). Jamal: Red Shirts mean business. The Star. Retrieved from http://www.thestar.com.my/news/nation/2016/11/12/red-shirts-meanbusiness-warn-bersih/ 
Malaysiakini. (2016, November 19). Yellow, red rallies end peacefully. Retrieved from http://www.malaysiakini.com/news/363399

Radue, M. (2012). The Internet's role in the Bersih movement in Malaysia-A Case Study. International Review of Information Ethics, 18, 12.

Schwarzmantel, J. J. (2011). Democracy and political violence. Edinburgh: Edinburgh University Press.

The Malay Mail Online. (2016, November 19). Red Shirts gather to counter Bersih 5 rally. Retrieved from http://www.themalaymailonline.com/malaysia/article/red-shirtsgather-to-counter-bersih-5-rally

The Straits Times. (2015, August 27). What you need to know about Malaysia's Bersih movement. Retrieved from http://www.straitstimes.com/asia/seasia/what-you-need-to-know-about-malaysias-bersih-movement

Thiruchelvam, C. C. (2011). The evolving media culture that is transforming and being transformed by local identities. JATI, 16, 77-95. 